\title{
Portuguese propolis disturbs glycolytic metabolism of human colorectal cancer in vitro
}

\author{
Isabel Valença ${ }^{1,2,3}$, Filipa Morais-Santos ${ }^{1,2}$, Vera Miranda-Gonçalves ${ }^{1,2}$, Ana Margarida Ferreira4, \\ Cristina Almeida-Aguiar ${ }^{3}$ and Fátima Baltazar ${ }^{1,2^{*}}$
}

\begin{abstract}
Background: Propolis is a resin collected by bees from plant buds and exudates, which is further processed through the activity of bee enzymes. Propolis has been shown to possess many biological and pharmacological properties, such as antimicrobial, antioxidant, immunostimulant and antitumor activities. Due to this bioactivity profile, this resin can become an alternative, economic and safe source of natural bioactive compounds. Antitumor action has been reported in vitro and in vivo for propolis extracts or its isolated compounds; however, Portuguese propolis has been little explored. The aim of this work was to evaluate the in vitro antitumor activity of Portuguese propolis on the human colon carcinoma cell line HCT-15, assessing the effect of different fractions (hexane, chloroform and ethanol residual) of a propolis ethanol extract on cell viability, proliferation, metabolism and death.

Methods: Propolis from Angra do Heroísmo (Azores) was extracted with ethanol and sequentially fractionated in solvents with increasing polarity, n-hexane and chloroform. To assess cell viability, cell proliferation and cell death, Sulforhodamine B, BrDU incorporation assay and Anexin V/Propidium iodide were used, respectively. Glycolytic metabolism was estimated using specific kits.
\end{abstract}

Results: All propolis samples exhibited a cytotoxic effect against tumor cells, in a dose- and time-dependent way. Chloroform fraction, the most enriched in phenolic compounds, appears to be the most active, both in terms of inhibition of viability and cell death. Data also show that this cytotoxicity involves disturbance in tumor cell glycolytic metabolism, seen by a decrease in glucose consumption and lactate production.

Conclusion: Our results show that Portuguese propolis from Angra do Heroísmo (Azores) can be a potential therapeutic agent against human colorectal cancer.

Keywords: Antitumor activity, Colorectal cancer, Glycolytic metabolism, HCT-15 cells, Propolis

\section{Background}

Propolis is a resin containing a complex mixture of compounds that honeybees collect from several plants, further digest with salivary enzymes and mix with beeswax. Propolis is composed mainly by wax and resin, but also contains essential oils, pollen, phenolic acids or their esters, flavonoids, terpenes, aromatic aldehydes, alcohols, and fatty acids, among others [1]. Propolis composition depends on various factors such as the source of plant species from which propolis is made and on environmental

\footnotetext{
* Correspondence: fbaltazar@ecsaude.uminho.pt

'Life and Health Sciences Research Institute (ICVS), School of Health Sciences, University of Minho, Braga, Portugal

${ }^{2}$ ICVS/3B's - PT Government Associate Laboratory, Braga/Guimarães, Portugal Full list of author information is available at the end of the article
}

factors, which constitute a difficulty to its standardization $[2,3]$. For instance, Brazilian propolis is composed essentially by prenylated $p$-coumaric acids and diterpenic acids [4], whereas propolis of temperate zones is mainly composed by flavones, flavanones, cinnamic acids and their esters $[2,5]$. Although scarcely studied, Portuguese propolis appears to be composed by the typical phenolic acids and flavonoids found in samples of temperate zones, especially in Europe, but it contains also several other new compounds that had never been referred before [6].

Propolis has been extensively employed in folk medicine since ancient times. Recently, a wide range of biological and pharmacological actions have been demonstrated for several types of propolis, such as antibacterial 
$[7,8]$, anti-fungal [8,9], anti-viral [10], anti-inflammatory $[11,12]$, antioxidant $[13,14]$, hepatoprotective [15], immunostimulant [16] and antitumor activities [13,17-19], among others.

Portuguese propolis pharmacological properties have been little explored. In fact, this resin has been highly neglected by both beekeepers and the scientific community. Only its chemical composition [6,20], antioxidant activity $[13,20,21]$ and antitumor activity on renal cell carcinoma [13] have been studied on a few samples of some regions of Portugal. These few studies revealed diversity in terms of chemical composition and biological properties, as well as the presence of some compounds never found in propolis from other origins [6], renewing the interest in studying this natural compound.

Thus, the aim of this work was to assess and characterize the antitumor activity of a propolis sample collected in Angra do Heroísmo (Archipelago of Azores, Portugal) in a colon cancer cell line, including its effects on tumour cell glycolytic metabolism. Despite evidence that some compounds occasionally present in propolis are able to inhibit lactate transport [22-26], to the best of our knowledge, propolis potential in disturbing cancer cell metabolism was never investigated.

\section{Methods}

\section{Preparation of propolis extracts and fractions}

Propolis was collected in March 2009 from Apis mellifera beehives located in Angra do Heroísmo (AH), Azores, Portugal. Propolis (40 g) was frozen at $-18^{\circ} \mathrm{C}$, grounded and extracted at room temperature with ethanol under slow stirring. The obtained solution was filtered and re-extracted twice more under the same conditions, giving the ethanol extract (EE) after filtration and solvent evaporation. This sample was designated AH.EE.09. The extract was further and sequentially fractionated in solvents with increasing polarity - $n$ hexane $(\mathrm{H})$ and chloroform $(\mathrm{C})$ - yielding, after solvent removal at $40^{\circ} \mathrm{C}$ under vacuum, the hexane (AH.FH.09) and the chloroform fractions (AH.FC.09) of propolis and a residual ethanol extract fraction (AH.FEr.09). Dried fractions were stored at $4{ }^{\circ} \mathrm{C}$ and were diluted in DMSO to obtain the working solutions at the desired concentrations.

Determination of total polyphenol and flavonoid contents Total phenolic content was determined according to the Folin-Ciocalteu colorimetric method [27], with some modifications, and using gallic acid as standard.

Total flavonoid content was quantified according to the method described by Woisky and Salatino [28], with some modifications. Quercetin was used as standard for total flavonoid content quantification.

\section{Cell culture}

The experiments were performed on the human colorectal adenocarcinoma cell line HCT-15. Cells were grown in RPMI 1640 medium (Gibco, Invitrogen, USA) supplemented with $10 \%$ fetal bovine serum (Gibco, Invitrogen, USA) and $1 \%$ penicillin/streptomycin (Invitrogen, USA). Cells were incubated at $37^{\circ} \mathrm{C}$ in atmosphere containing $5 \% \mathrm{CO}_{2}$.

\section{Cell viability assay}

Cell viability was measured by the sulforhodamine B assay (Sigma Chemical Company, MO, USA) following the manufacturer's instructions. HCT-15 cells were incubated in 96-well plates $\left(1 \times 10^{4}\right.$ cells/well) with different concentrations $(0.005 \mathrm{mg} / \mathrm{ml}-0.05 \mathrm{mg} / \mathrm{ml})$ of propolis samples for 24, 48 and 72 hours. Controls were treated with DMSO alone (1\%).

Results are presented as mean \pm SD of three independent experiments, each in triplicate. IC50 values were calculated for each propolis fraction and time point.

\section{Cell proliferation assay}

Cell proliferation was measured using the 5-bromo-2'deoxyuridine (BrdU) Cell Proliferation Assay (Roche, Mannheim, Germany). HCT-15 cells were incubated in 96-well plates $\left(1 \times 10^{4}\right.$ cells/well) for 24 hours with the half maximal inhibitory concentrations $\left(\mathrm{IC}_{50} \mathrm{~s}\right)$ and two higher concentrations $(0.025$ and $0.05 \mathrm{mg} / \mathrm{ml})$ of $\mathrm{AH}$. FC.09 and AH.FEr.09. Controls were treated with DMSO alone $(1 \%)$. BrdU was added after 24 hours of propolis exposure and was quantified according to the manufacturer's instructions using a microplate reader (Model 680, Bio Rad) at $450 \mathrm{~nm}$.

Results are presented as mean \pm SD of three independent experiments, each in triplicate.

\section{Cell metabolism assay}

Extracellular glucose and lactate were measured using commercial kits for glucose (Cobas, Roche) and lactate (Spinreact, S.A.U.) according to the manufacturer's protocols, but scaled down to microplate

Table 1 Total polyphenol and flavonoid contents of propolis were determined in all the fractions of Angra do Heroísmo propolis

\begin{tabular}{lll}
\hline & Total polyphenols $(\mathbf{m g} / \mathbf{m l})$ & Total flavonoids $(\mathbf{m g} / \mathbf{m l})$ \\
\hline AH. FH.09 & $134.3 \pm 1.3$ & $13.5 \pm 0.4$ \\
AH.FC.09 $^{\text {b) }}$ & $214.8 \pm 9.1$ & $25.5 \pm 0.6$ \\
AH.FEr.09 $^{\text {c) }}$ & $194.0 \pm 4.7$ & $26.9 \pm 0.4$ \\
\hline
\end{tabular}

Each value indicates mean \pm SD.

a) Hexane fraction.

b) Chloroform fraction.

c) Ethanol residual fraction. 

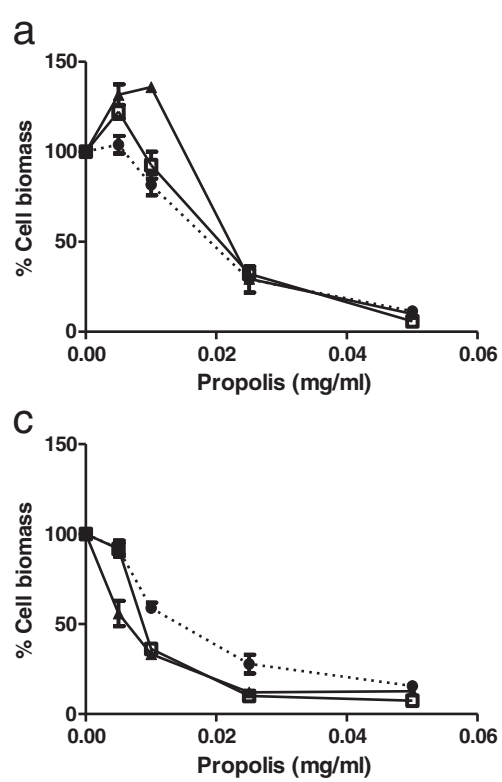

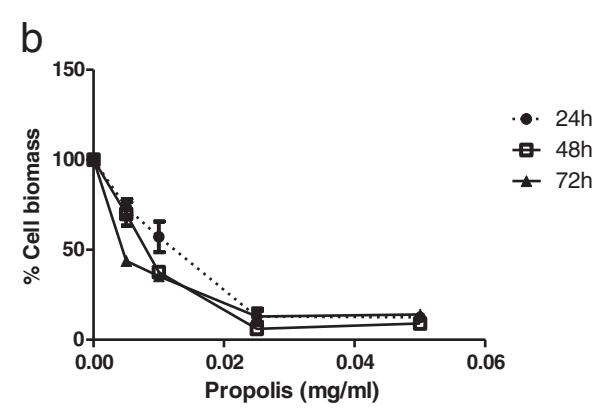

Figure 1 Effect of propolis on HCT-15 cell viability. HCT-15 cells were treated for 24,48 and $72 \mathrm{~h}$ with different concentrations of propolis fractions - AH.FH.09 (a), AH.FC.09 (b) and AH.FEr.09 (c) - and control cells were treated with DMSO alone. Results are expressed as percentage of cell biomass.

volumes. HCT-15 cells were incubated for 24 hours in 24-well plates $\left(4 \times 10^{5}\right.$ cells/well $)$ with the $\mathrm{IC}_{50}$ concentrations for AH.FC.09 and AH.FEr.09, at 24 hours, and two higher concentrations (see above). Controls were treated with DMSO alone (1\%).

Results are presented as mean \pm SD of three independent experiments, each in triplicate.

\section{Cell death assay}

Apoptotic and necrotic cell populations were determined by Annexin V (BD Biosciences). Briefly, HCT15 cells were seeded in T25 flasks and incubated until 90\% confluence. Cells were treated with $\mathrm{AH}$. FC.09 and AH.FEr.09 at $\mathrm{IC}_{50}$ concentrations for 24 hours. Controls were treated with DMSO alone (1\%). After incubation, culture supernatant was recovered from each flask and treated cells were trypsinized. Cell pellets were ressuspended in $1 \mathrm{ml}$ binding buffer (10 mM Hepes $\mathrm{pH} 7.4,140 \mathrm{mM} \mathrm{NaCl}$ and $2.5 \mathrm{mM} \mathrm{CaCl}_{2}$ ) and centrifuged at $2000 \mathrm{rpm} \times$ $5 \mathrm{~min}$. Then, cells were incubated $15 \mathrm{~min}$. with staining solution $(8 \mu \mathrm{l}$ Annexin and $30 \mu \mathrm{l} \mathrm{PI}(50 \mu \mathrm{g} / \mathrm{ml})$ per $100 \mu \mathrm{l}$ of binding buffer) at room temperature. The percentage of cell death was assessed by flow cytometry (LSRII model, BD Biosciences): a total of 20,000 events was recovered and the results were analyzed using the FlowJo software (version 7.6; Tree Star, Inc.).
Results are presented as mean \pm SD of three independent experiments.

\section{Statistical analysis}

Statistic analysis was performed using the GraphPad Prism. Unpaired $t$-test was performed to compare two groups. Significance was considered as $p<0.05$.

\section{Results}

\section{Propolis polyphenol and flavonoid contents}

The values for total polyphenol and flavonoid contents (Table 1) show that AH.FC.09 has the greatest amount $(214.8 \mathrm{mg} / \mathrm{ml})$ whereas AH.FH.09 exhibits the lowest amount (134.3 $\mathrm{mg} / \mathrm{ml}$ of polyphenols). Concerning flavonoid content, AH.FC.09 and AH.FEr.09 have similar amounts - 25.5 and $26.9 \mathrm{mg} / \mathrm{ml}$ respectively - and $\mathrm{AH}$. FH.09 presents the lowest amount of flavonoids (13.5 $\mathrm{mg} / \mathrm{ml})$.

Table 2 IC $_{50}$ values of propolis fractions - AH.FH.09, AH. FC.09 and AH.FEr.09 - on HCT-15 cell line

\begin{tabular}{|c|c|c|c|}
\hline & AH.FH.09 $(\mathrm{mg} / \mathrm{ml})$ & AH.FC. $\left.09^{b}\right)(\mathrm{mg} / \mathrm{ml})$ & AH.FEr.09 $(\mathrm{mg} / \mathrm{ml})$ \\
\hline $24 \mathrm{~h}$ & 0.020 & 0.01 & 0.015 \\
\hline $48 \mathrm{~h}$ & 0.024 & 0.007 & 0.009 \\
\hline $72 \mathrm{~h}$ & 0.026 & 0.005 & 0.005 \\
\hline
\end{tabular}

a) Hexane fraction of Angra do Heroísmo propolis collected in 2009. b) Chloroform fraction of Angra do Heroísmo propolis collected in 2009. c) Ethanol residual fraction of Angra do Heroísmo propolis collected in 2009. 

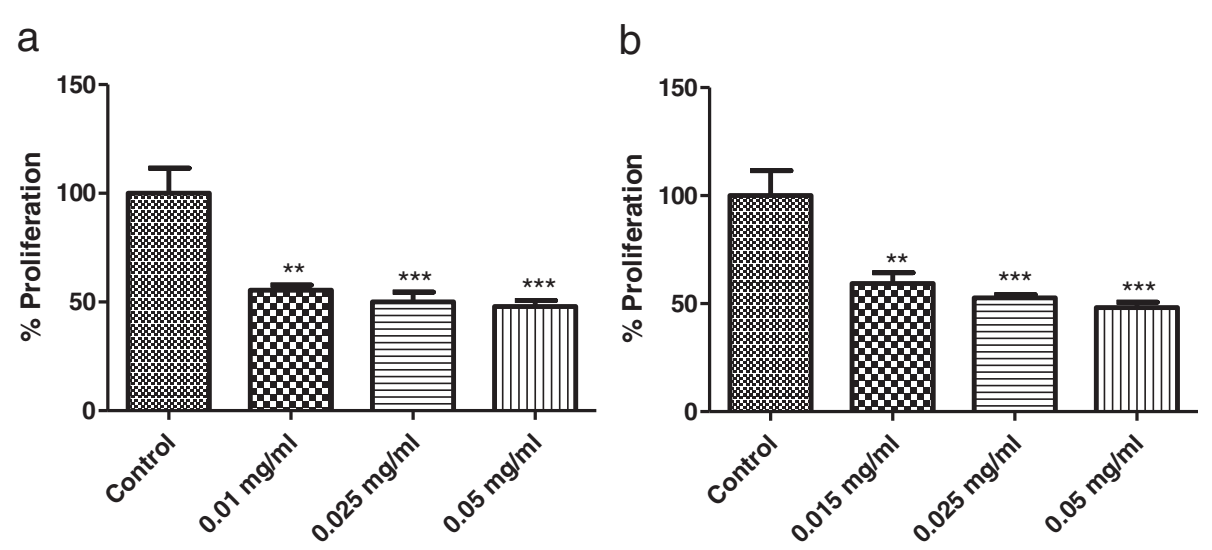

Figure 2 Effect of different concentrations of propolis fractions - AH.FC.09 (a) and AH.FEr.09 (b) - on HCT-15 cell proliferation. Controls were treated with DMSO alone. Results are presented as percentage of proliferation. ${ }^{* *} p<0.01$ vs control. ${ }^{* *} p<0.001$ vs control.

\section{Effect of propolis fractions on cell viability}

The effect of propolis fractions on the viability of HCT15 cells was assessed by the sulforhodamine B assay (Figure 1). Cells were incubated for 24, 48 and 72 hours with different concentrations of propolis fractions. All propolis samples led to a decrease in cell biomass of HCT-15 cells in a dose- and time-dependent manner, with $\mathrm{IC}_{50}$ values ranging from 0.005 to $0.026 \mathrm{mg} / \mathrm{ml}$ (Figure 1 and Table 2). AH.FC.09 appears to be the most effective and AH.FH.09 the least effective in decreasing cell viability (Figure 1). At low concentrations AH.FH.09 seems to increase cell biomass, mainly after 48 and 72 hours incubation (Figure 1a).

\section{Effect of propolis fractions on cell proliferation}

To assess the effect of propolis on cell proliferation, HCT-15 cells were treated with $\mathrm{IC}_{50}$ concentrations, as well as two higher concentrations of the most effective fractions, AH.FC.09 and AH.FEr.09.

Both fractions were able to decrease HCT-15 cell proliferation (Figure 2). All tested concentrations of propolis led to a decrease of approximately $40-60 \%$ in cell proliferation after 24 hours of incubation.

\section{Effect of propolis fractions on cell metabolism}

After 24 hours of incubation with different concentrations ( $\mathrm{IC}_{50}$ and two higher concentrations) of AH.FC.09
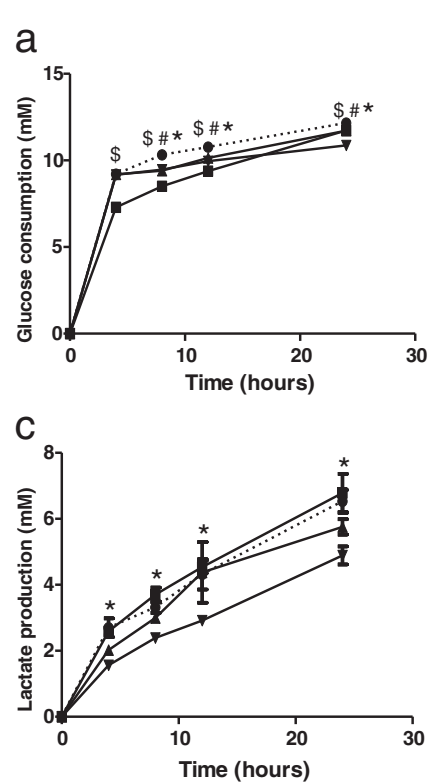
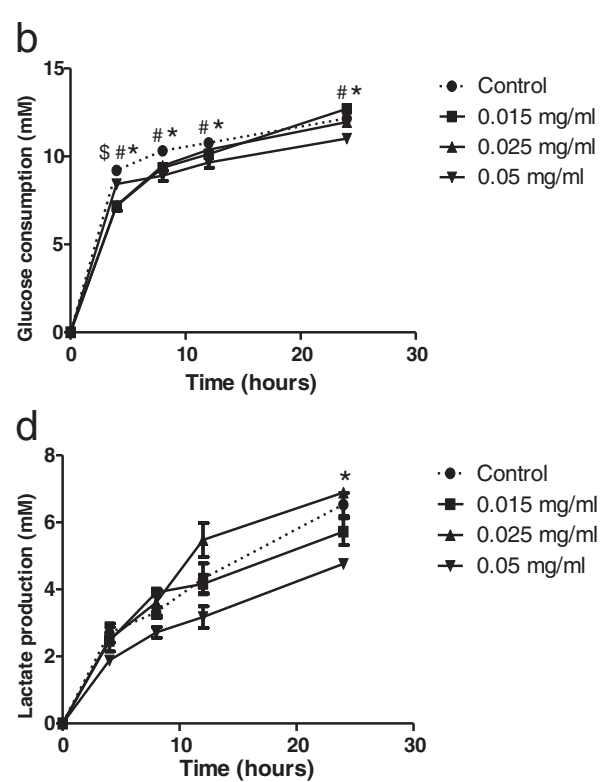

Figure 3 Effect of propolis on HCT-15 cell metabolism. HCT-15 cells were treated with several concentrations of AH.FC.09 (a,c) and AH.FEr.09 $\mathbf{( b , d )}$. Controls were treated with DMSO alone. Results are presented as glucose consumption $(\mathbf{a}, \mathbf{b})$ and lactate production $(\mathbf{c}, \mathbf{d}) .{ }^{\$} \mathrm{p}<0.05,0.01 /$ $0.015 \mathrm{mg} / \mathrm{ml}$ vs control; \# $\mathrm{p}<0.05,0.025 \mathrm{mg} / \mathrm{ml}$ vs control; ${ }^{*} \mathrm{p}<0.050 .05 \mathrm{mg} / \mathrm{ml}$ vs control. 
and AH.FEr.09, there was a decrease in the glycolytic metabolism of HCT-15 cells (Figure 3). AH.FC.09 led to a decrease in glucose consumption and lactate production along 24 hours of incubation (Figure 3a,c). AH.FEr.09 led to a decrease in glucose consumption along 24 hours, however, lactate production only decreased after 24 hours of incubation with $0.05 \mathrm{mg} / \mathrm{ml}$ (Figure 3b,d).

\section{Effect of propolis fractions on cell death}

To evaluate the effect of propolis on cell death, HCT-15 cells were incubated with the $\mathrm{IC}_{50}$ values of each fraction for 24 hours. AH.FC.09 and AH.FEr.09 fractions moderately induced cell death on HCT-15 cells, about $7 \%$ and $5 \%$, respectively (Figure 4 ).

\section{Discussion}

Propolis has been widely studied for its biological properties and has been used by several industries, such as food, cosmetics and pharmaceutical industries [2,29]. In vitro and in vivo studies on propolis antitumor activity have been widely reported [13,18,30-35], however, there is only one study exploring Portuguese propolis with this purpose [13,18,30-35], where the authors reported inhibition of human renal cancer cell growth.

In the present study, we aimed to assess the antitumor activity of a fractionated Portuguese propolis sample collected in Angra do Heroísmo, an island of the Azores Archipelago, on HCT-15 colon cancer cell line. This is the first study to assess antitumor activity in this tumor model and with Portuguese propolis.

Our results showed that all propolis fractions were able to decrease cell viability of colon tumor cells (Figure 1), being in accordance with previous reports [30,32-35]. However, lower concentrations of the hexane fraction seem to increase the number of viable cells (Figure 1a). Propolis is a mixture of several compounds from plants and since this solvent has low polarity, the hexane fraction has lower amounts of dissolved polyphenols and flavonoids than
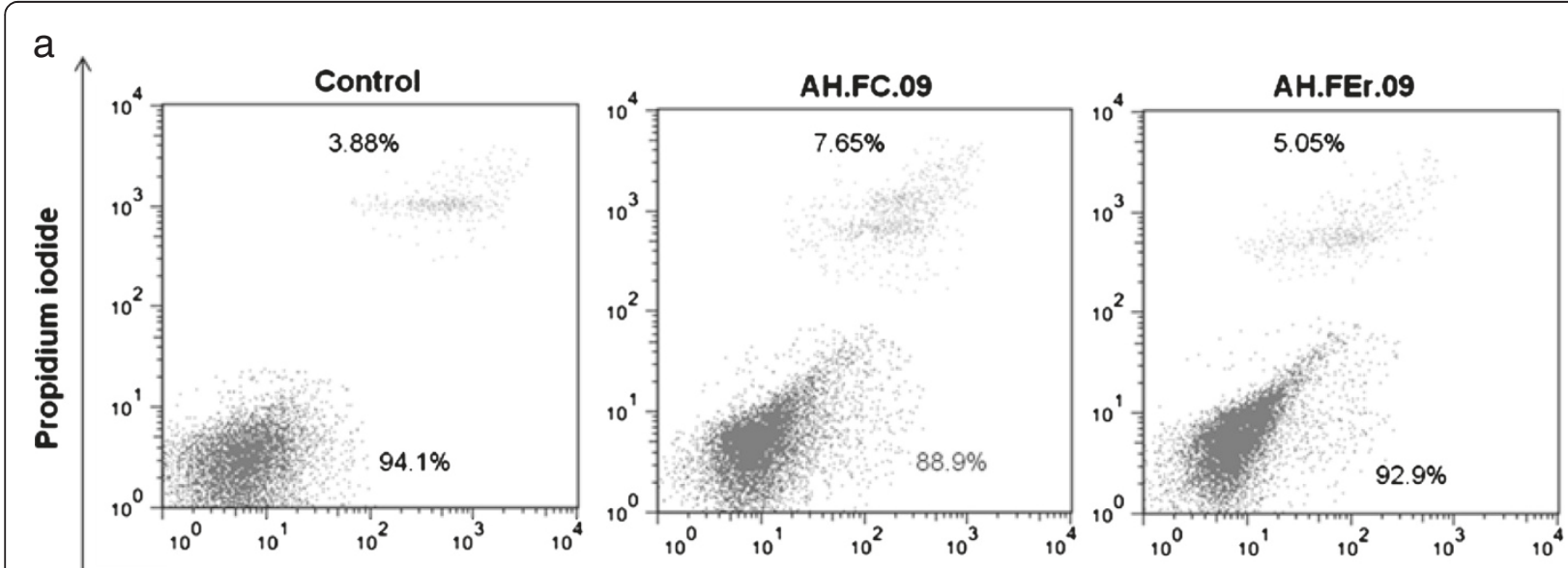

Annexin V

b

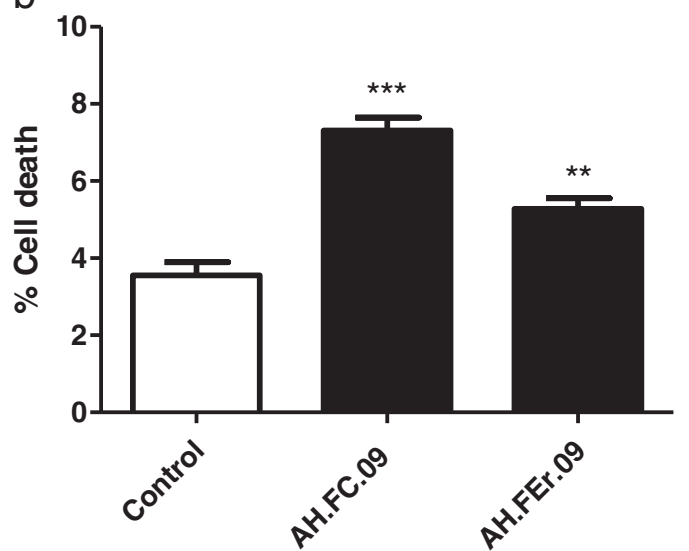

Figure 4 Effect of propolis on HCT-15 cell death. Representative dotplot of cell population distribution stained for Annexin V and PI (a) and graphic representation (b). Cells were treated with $I_{50}$ concentrations for 24 hours and control was treated with DMSO alone. Results are presented as percentage of cell death. ${ }^{* *} p<0.01$ vs control. ${ }^{* *} p<0.001$ vs control. 
chloroform or ethanol fractions (Table 1), both considered the main bioactive compounds in European propolis. This is probably why this fraction was not able to decrease cell viability when tested at low concentration. The chloroform fraction seems to be more powerful in decreasing cell viability (Figure 1b), which may be due to the presence of superior amounts of compounds of higher polarity, like the phenolic compounds (Table 1), which are more efficiently extracted with chloroform than hexane.

Since AH.FC.09 and AH.FEr.09 were the most effective fractions, we further assessed its effects on cell proliferation, metabolism and death. The results show that propolis led to a decrease in HCT-15 cell proliferation (Figure 2), as described in other studies [33-35]. Regarding the effect of propolis on cell death, there was a small induction in cell death (Figure 4), again in accordance with results of other reports concerning other propolis samples [30,31]. Ishihara et al. [30] showed that Chinese and Brazilian propolis induced apoptosis in cell cultures of human colon carcinoma cells. Also, Szliszka et al. [31] showed that tumor necrosis factor-related apoptosisinducing ligand (TRAIL) in prostate cancer cells is markedly augmented by a propolis ethanol extract from Poland.

The cytotoxic effect of the studied propolis fractions may be related to the overall effect of their phenolic compounds. Over the last decades, several phenolic compounds (mainly flavonoids and phenolic acids) have been linked to propolis antitumor activity against colorectal tumor cells in vitro. Among flavonoids, quercetin is able to inhibit cell growth with cytotoxic activity [36,37], to reduce cell proliferation [38], induce cell cycle arrest and apoptosis [37,39]. Apigenin, another flavonoid, can induce cell cycle arrest and apoptosis [40,41]; rutin is able to inhibit cell proliferation and induce apoptosis [42,43]; galangin shows antiproliferative capacities [35] and chrysin is able to inhibit cell growth, reduce cell proliferation, induce cell cycle arrest and apoptosis $[35,42,43]$. In what concerns phenolic acids, cinnamic acid displayed antiproliferative effects $[35,44]$ and caffeic acid phenethyl ester (CAPE) inhibited proliferation [35] and induced growth arrest and apoptosis [45].

To the best of our knowledge, propolis effect on glycolytic metabolism of cancer cells has not yet been investigated. The present study shows for the first time that a Portuguese propolis sample has antitumor activity on HCT-15 colon cancer cell line and that such activity likely involves disturbance of tumor cell metabolism, as assessed by the effects on the rates of glucose consumption and lactate production (Figure 3). It is known that cancer cells have preference for glycolytic metabolism, displaying higher glycolytic rates than those of normal cells [46]. In normal cells and in the presence of oxygen, pyruvate undergoes oxidative phosphorylation, leading to highly efficient energy production in the form of ATP.
However, if oxygen levels are low, pyruvate is converted into lactate in the cytoplasm, a process much less efficient in terms of energy production. In the case of tumor cells, pyruvate is preferentially converted to lactate even in the presence of oxygen, a process known as the Warburg effect [46]. To maintain intracellular $\mathrm{pH}$, and to avoid cell death, tumor cells use beyond other $\mathrm{pH}$ regulators, monocarboxylate transporters (MCTs) for proton-coupled lactate efflux and maintenance of glycolytic rates [47]. Therefore, if the activity of these transporters is inhibited, there will be an increase of intracellular lactate and consequent impairment of glycolysis, with a consequent decrease in glucose consumption [48].

Although propolis effect on glycolytic metabolism of cancer cells has not yet been investigated, there are some studies that associate a wide range of phenolic compounds, some present in propolis samples, to glycolytic metabolism inhibition. Shim et al. [22] showed that the flavonoids naringenin, morin, silybin and quercetin are competitive inhibitors of MCT1 in Caco-2 colon cancer cells. Also, Wang et al. [23] showed that several flavonoids, such as apigenin, biochanin A, chrysin, diosemin, fisetin, genistein, hesperitin, kaempferol, luteolin, morin, narigenin, phloretin, and quercetin may significantly alter the pharmacokinetics and pharmacodynamics of MCT1 substrates. Phenolic acids can also be responsible for MCT inhibition. Alpha-cyano-4-hydroxycinnamic acid, a cinnamic acid derivative, has been associated with MCT activity inhibition in several tumor models [24-26]. However, further studies are needed to understand the mechanism by which propolis affects cell glycolytic metabolism, namely if it is mediated by inhibition of lactate transport through MCTs.

\section{Conclusions}

The cytotoxicity of the Portuguese propolis sample studied appears to be due not only to a decrease in cell proliferation and induction of cell death but also to disturbance of cancer cell glycolytic metabolism. Overall, these results support that Portuguese propolis or its components should be further explored as therapeutic agents in the treatment of cancer.

\section{Competing interests}

The authors declare no conflicts of interest.

\section{Authors' contributions}

IV conducted most of the experimental work and wrote the first draft of the manuscript. FMS supervised and helped in the in vitro assays. VG performed the cytometry studies and helped writing the manuscript. AMF provided and prepared propolis samples. CAA and FB conceived and designed the study, coordinated its development and corrected the manuscript. All authors read and approved the final manuscript.

\section{Acknowledgements}

We thank the Portuguese Science and Technology Foundation (FCT) for VMG fellowship (ref. SFRH/BI/33503/2008). The authors thank Mr. António 
Marques from Frutercoop - Azores, who kindly collected and provided the propolis sample for the study.

\section{Author details}

'Life and Health Sciences Research Institute (ICVS), School of Health Sciences, University of Minho, Braga, Portugal. ${ }^{2}$ ICVS/3B's - PT Government Associate Laboratory, Braga/Guimarães, Portugal. ${ }^{3} \mathrm{CBMA}$ - Centre of Molecular and Environmental Biology, Biology Department, University of Minho, Braga, Portugal. ${ }^{4}$ Chemistry Centre Vila Real (CQVR), University of Trás-os-Montes e Alto Douro, Vila Real, Portugal.

Received: 5 September 2012 Accepted: 5 July 2013

Published: 19 July 2013

\section{References}

1. Bankova VS, Popov SS, Marekov NL: A study on flavonoids of propolis. I Nat Prod 1983, 46:471-474.

2. Marcucci MC: Propolis: chemical composition, biological properties and therapeutic activity. Apidologie 1995, 26(2):83-99.

3. Bankova V: Chemical diversity of propolis and the problem of standardization. J Ethnopharmacol 2005, 100(1-2):114-117.

4. Bankova VS, De Castro SL, Marcucci MC: Propolis: recent advances in chemistry and plant origin. Apidologie 2000, 31:3-15.

5. Greenaway W, Scaysbrook T, Whatley FR: The composition and plant origins of propolis: a report of work at Oxford. Bee World 1990, 71(3):107-118.

6. Falcao SI, Vilas-Boas M, Estevinho LM, Barros C, Domingues MR, Cardoso SM: Phenolic characterization of Northeast Portuguese propolis: usual and unusual compounds. Anal Bioanal Chem 2010, 396(2):887-897.

7. Scazzocchio F, D'Auria FD, Alessandrini D, Pantanella F: Multifactorial aspects of antimicrobial activity of propolis. Microbiol Res 2006, 161(4):327-333.

8. Kujumgiev A, Tsvetkova I, Serkedjieva Y, Bankova V, Christov R, Popov S: Antibacterial, antifungal and antiviral activity of propolis of different geographic origin. J Ethnopharmacol 1999, 64(3):235-240.

9. Silici S, Koc NA, Ayangil D, Cankaya S: Antifungal activities of propolis collected by different races of honeybees against yeasts isolated from patients with superficial mycoses. J Pharmacol Sci 2005, 99(1):39-44.

10. Amoros M, Simoes CM, Girre L, Sauvager F, Cormier M: Synergistic effect of flavones and flavonols against herpes simplex virus type 1 in cell culture comparison with the antiviral activity of propolis. J Nat Prod 1992, 55(12):1732-1740.

11. Mirzoeva OK, Calder PC: The effect of propolis and its components on eicosanoid production during the inflammatory response. Prostaglandins Leukot Essent Fatty Acids 1996, 55(6):441-449.

12. Hu F, Hepburn HR, Li Y, Chen M, Radloff SE, Daya S: Effects of ethanol and water extracts of propolis (bee glue) on acute inflammatory animal models. J Ethnopharmacol 2005, 100(3):276-283.

13. Valente MJ, Baltazar AF, Henrique R, Estevinho L, Carvalho M: Biological activities of Portuguese propolis: protection against free radical-induced erythrocyte damage and inhibition of human renal cancer cell growth in vitro. Food Chem Toxicol 2011, 49(1):86-92.

14. Russo A, Longo R, Vanella A: Antioxidant activity of propolis: role of caffeic acid phenethyl ester and galangin. Fitoterapia 2002, 73(Suppl 1):S21-S29.

15. Seo KW, Park M, Song YJ, Kim SJ, Yoon KR: The protective effects of Propolis on hepatic injury and its mechanism. Phytother Res 2003, 17(3):250-253.

16. Pagliarone AC, Orsatti CL, Bufalo MC, Missima F, Bachiega TF, Junior JP, Sforcin JM: Propolis effects on pro-inflammatory cytokine production and Toll-like receptor 2 and 4 expression in stressed mice. Int Immunopharmacol 2009, 9(11):1352-1356.

17. Lin WL, Liang WH, Lee YJ, Chuang SK, Tseng TH: Antitumor progression potential of caffeic acid phenethyl ester involving p75(NTR) in C6 glioma cells. Chem Biol Interact 2010, 188(3):607-615.

18. Oršolić N, Bašić I: Water-soluble derivative of propolis and its polyphenolic compounds enhance tumoricidal activity of macrophages. J Ethnopharmacol 2005, 102(1):37-45.

19. Basini G, Baioni L, Bussolati S, Grasselli F, Daquino C, Spatafora C, Tringali C Antiangiogenic properties of an unusual benzo [k, l] xanthene lignan derived from CAPE (Caffeic Acid Phenethyl Ester). Invest New Drugs 2012, 30(1):186-190
20. Miguel MG, Nunes S, Dandlen SA, Cavaco AM, Antunes MD: Phenols and antioxidant activity of hydro-alcoholic extracts of propolis from Algarve South of Portugal. Food Chem Toxicol 2010, 48(12):3418-3423.

21. Moreira L, Dias LG, Pereira JA, Estevinho L: Antioxidant properties, total phenols and pollen analysis of propolis samples from Portugal. Food Chem Toxicol 2008, 46(11):3482-3485.

22. Shim CK, Cheon EP, Kang KW, Seo KS, Han HK: Inhibition effect of flavonoids on monocarboxylate transporter 1 (MCT1) in Caco-2 cells. J Pharm Pharmacol 2007, 59(11):1515-1519.

23. Wang Q, Morris ME: Flavonoids modulate monocarboxylate transporter-1 -mediated transport of gamma-hydroxybutyrate in vitro and in vivo. Drug Metab Dispos 2007, 35(2):201-208.

24. Colen CB, Shen Y, Ghoddoussi F, Yu P, Francis TB, Koch BJ, Monterey MD, Galloway MP, Sloan AE, Mathupala SP: Metabolic targeting of lactate efflux by malignant glioma inhibits invasiveness and induces necrosis: an in vivo study. Neoplasia 2011, 13(7):620-632.

25. Coss RA, Storck CW, Daskalakis C, Berd D, Wahl ML: Intracellular acidification abrogates the heat shock response and compromises survival of human melanoma cells. Mol Cancer Ther 2003, 2(4):383-388.

26. Fang J, Quinones QJ, Holman TL, Morowitz MJ, Wang Q, Zhao H, Sivo F, Maris JM, Wahl ML: The $\mathrm{H}+$-linked monocarboxylate transporter (MCT1/ SLC16A1): a potential therapeutic target for high-risk neuroblastoma. Mol Pharmacol 2006, 70(6):2108-2115.

27. Singleton $\mathrm{VL}$, Orthofer R, Lamuela-Raventós RM: Analysis of total phenols and other oxidation substrates and antioxidants by means of folinciocalteu reagent. Methods Enzymol 1999, 299:152-178.

28. Woisky RG, Salatino A: Analysis of propolis: some parameters and procedures for chemical quality control. J Apicult Res 1999, 37(2):99-105.

29. Pereira A, Seixas F, Silva M: Propolis: 100 years of research and future perspectives. Soc Brasileira Quimica 2002, 25(2):321-326.

30. Ishihara M, Naoi K, Hashita M, Itoh Y, Suzui M: Growth inhibitory activity of ethanol extracts of Chinese and Brazilian propolis in four human colon carcinoma cell lines. Oncol Rep 2009, 22(2):349-354.

31. Szliszka E, Czuba ZP, Bronikowska J, Mertas A, Paradysz A, Krol W: Ethanolic extract of propolis augments TRAIL-induced apoptotic death in prostate cancer cells. Evid Based Complement Alternat Med 2011. doi:10.1093/ecam/nep180.

32. Li F, Awale S, Tezuka Y, Kadota S: Cytotoxicity of constituents from Mexican propolis against a panel of six different cancer cell lines. Nat Prod Commun 2010, 5(10):1601-1606.

33. Pratsinis H, Kletsas D, Melliou E, Chinou I: Antiproliferative activity of Greek propolis. J Med Food 2010, 13(2):286-290.

34. Russo A, Cardile V, Sanchez F, Troncoso N, Vanella A, Garbarino JA: Chilean propolis: antioxidant activity and antiproliferative action in human tumor cell lines. Life Sci 2004, 76(5):545-558.

35. Banskota AH, Nagaoka T, Sumioka LY, Tezuka Y, Awale S, Midorikawa K, Matsushige K, Kadota S: Antiproliferative activity of the Netherlands propolis and its active principles in cancer cell lines. J Ethnopharmacol 2002, 80(1):67-73.

36. Ramos S: Cancer chemoprevention and chemotherapy: dietary polyphenols and signalling pathways. Mol Nutr Food Res 2008, 52(5):507-526.

37. Kim WK, Bang MH, Kim ES, Kang NE, Jung KC, Cho HJ, Park JH: Quercetin decreases the expression of ErbB2 and ErbB3 proteins in HT-29 human colon cancer cells. J Nutr Biochem 2005, 16(3):155-162.

38. Dihal AA, Woutersen RA, Van Ommen B, Rietjens IM, Stierum RH: Modulatory effects of quercetin on proliferation and differentiation of the human colorectal cell line Caco-2. Cancer Lett 2006, 238(2):248-259.

39. Ramos S: Effects of dietary flavonoids on apoptotic pathways related to cancer chemoprevention. J Nutr Biochem 2007, 18(7):427-442.

40. Turktekin M, Konac E, Onen HI, Alp E, Yilmaz A, Menevse S: Evaluation of the effects of the flavonoid apigenin on apoptotic pathway gene expression on the colon cancer cell line (HT29). J Med Food 2011, 14(10):1107-1117.

41. Wang W, Heideman L, Chung CS, Pelling JC, Koehler KJ, Birt DF: Cell-cycle arrest at $\mathrm{G} 2 / \mathrm{M}$ and growth inhibition by apigenin in human colon carcinoma cell lines. Mol Carcinog 2000, 28(2):102-110.

42. Goncalves P, Araujo JR, Pinho MJ, Martel F: In vitro studies on the inhibition of colon cancer by butyrate and polyphenolic compounds. Nutr Cancer 2011, 63(2):282-294.

43. Kuntz $\mathrm{S}$, Wenzel $\mathrm{U}$, Daniel H: Comparative analysis of the effects of flavonoids on proliferation, cytotoxicity, and apoptosis in human colon cancer cell lines. Eur J Nutr 1999, 38(3):133-142. 
44. Ekmekcioglu C, Feyertag J, Marktl W: Cinnamic acid inhibits proliferation and modulates brush border membrane enzyme activities in Caco-2 cells. Cancer Lett 1998, 128(2):137-144.

45. Xiang D, Wang D, He Y, Xie J, Zhong Z, Li Z: Caffeic acid phenethyl ester induces growth arrest and apoptosis of colon cancer cells via the betacatenin/T-cell factor signaling. Anticancer Drugs 2006, 17(7):753-762.

46. Gatenby RA, Gillies RJ: Why do cancers have high aerobic glycolysis? Nat Rev Cancer 2004, 4(11):891-899.

47. Kaelin WG Jr, Thompson CB: Q\&A: cancer: clues from cell metabolism. Nature 2010, 465:562-564.

48. Pinheiro C, Longatto-Filho A, Azevedo-Silva J, Casal M, Schmitt FC, Baltazar F: Role of monocarboxylate transporters in human cancers: state of the art. J Bioenerg Biomembr 2012, 44:127-139.

doi:10.1186/1472-6882-13-184

Cite this article as: Valença et al:: Portuguese propolis disturbs glycolytic metabolism of human colorectal cancer in vitro. BMC Complementary and Alternative Medicine 2013 13:184.

\section{Submit your next manuscript to BioMed Central and take full advantage of:}

- Convenient online submission

- Thorough peer review

- No space constraints or color figure charges

- Immediate publication on acceptance

- Inclusion in PubMed, CAS, Scopus and Google Scholar

- Research which is freely available for redistribution 